\title{
Micropropagation of Agarita (Berberis trifoliata Moric.)
}

\author{
Francisco Molinar, Jr. \\ Department of Agronomy and Horticulture, New Mexico State University, Box \\ 30003, Department 3Q, Las Cruces, NM 88003
}

\author{
Wayne A. Mackay ${ }^{1}$ \\ Texas A\&M University Research and Extension Center, 1380 A\&M Circle, El \\ Paso, TX 79927
}

Marisa M. Wall

Department of Agronomy and Horticulture, New Mexico State University, Box 30003, Department 3Q, Las Cruces, NM 88003

\author{
Manuel Cardenas \\ Department of Experimental Statistics, New Mexico State University, Box \\ 3130, Las Cruces, NM 88003
}

Additional index words. tissue culture, Mahonia trifoliata, Berberidaceae

\begin{abstract}
Experiments were conducted to develop a clonal propagation system for agarita (Berberis trifoliata Moric.). Actively growing agarita shoots were collected from a mature plant at the Texas A\&M Univ. Research and Extension Center in EI Paso and successfully established on a basal medium consisting of woody plant medium (WPM) salts and Murashige and Skoog vitamins, sucrose at $30 \mathrm{~g} \cdot \mathrm{L}^{-1}$, and $0.8 \%$ Phytagar supplemented with 11.1 $\mu_{\mathrm{M}}$ BA. Cytokinins (benzyladenine, kinetin, and thidiazuron), subculture period, and age of cultures were tested. The optimal shoot proliferation conditions were WPM basal medium supplemented with $5.5 \mu \mathrm{M} B \mathrm{~B}$ and a subculture period of 4 weeks. Culture age did not affect shoot proliferation but did affect rooting. Preliminary experiments with $1.0 \mu \mathrm{M}$ NAA resulted in nearly $100 \%$ rooting of microshoots $<6$ months old. Shoots from 21 month-old cultures had to be placed on a cytokinin-free medium before successful rooting. On basal medium supplemented with NAA $(5.4 \mu \mathrm{M}), 68 \%$ of the microshoots rooted with an average of 1.2 secondary roots per microshoot. Chemical names used: $N$-(phenylmethyl)$1 H$-purin-6-amine (BA); 1-naphthaleneacetic acid (NAA); $N$-phenyl- $N^{\prime}-1,2,3$-thiadiazol5-ylurea (thidiazuron or TDZ); 6-furfurlaminopurine (kinetin).
\end{abstract}

Agarita is an evergreen shrub growing to $\approx 2 \mathrm{~m}$ in height under natural conditions. The plant thrives in the arid environment and alkaline soils commonly found in the Chihuahuan desert. Native populations propagated by seed exhibit wide variation in leaf morphology, color, and form. Selected superior plants have some desirable characteristics, including glossy, evergreen, sharp-pointed foliage; denser appearance; attractive flower color and form; disease resistance; and drought tolerance. Agarita may replace ill-adapted Ilex cultivars in the southwestern landscapes. However, agarita is difficult to root using traditional techniques and can be propagated only by seeds with the consequent unwanted genetic variation (Nokes, 1986). Micropropaga-

Received for publication 1 Dec. 1995. Accepted for publication 10 May 1996. This research was conducted at the Texas Agricultural Experiment Station El Paso, The Texas A\&M Univ. System. The cost of publishing this paper was defrayed in part by the payment of page charges. Under postal regulations, this paper therefore must be hereby marked advertisement solely to indicate this fact.

${ }^{1}$ To whom reprint requests should be addressed. tion can allow rapid and large-scale multiplication of superior clones and possibly enhance commercial production of selected plants. Successful micropropagation has been reported for Berberis thunbergii DC. using BA to induce shoot proliferation and rooting of the microshoots on auxin-free medium after a 7day induction period in darkness with IAA or $1 H$-indole-3-butyric acid (IBA) (Karhu and Hakala, 1991). The objective of our research was to develop a micropropagation protocol for the rapid multiplication of a superior agarita genotype, examining variables that affect shoot proliferation, shoot growth, and rooting of microcuttings.

\section{Materials and Methods}

Explant and culture establishment. Actively growing apical and axillary shoots $2 \mathrm{~cm}$ long were collected during the summer from an elite, mature, flowering agarita plant located at the Texas A\&M Research and Extension Center at El Paso. After leaf removal, shoots were surface-disinfested for $15 \mathrm{~min}$ in a continuously stirred $0.5 \%$ sodium hypochlorite (10\% Clorox) solution containing $0.1 \%$ Tween $20(\mathrm{v} / \mathrm{v})$ as a surfactant. Shoots then were rinsed three times in sterile distilled water, trimmed to $\approx 1.5 \mathrm{~cm}$ in length, and cultured on a basal medium. A short transfer period ( 3 days) during the first subculture was successful in eliminating phenolic compounds produced when first wounded, and activated charcoal was not necessary to remove phenolic compounds.

Medium. The basal medium consisted of woody plant medium (WPM) inorganic salts (Lloyd and McCown, 1980), Murashige and Skoog vitamins (Murashige and Skoog, 1962), sucrose at $30 \mathrm{~g} \cdot \mathrm{L}^{-1}$, and $0.8 \%$ Phytagar (Sigma type A). The basal medium was supplemented with $11.1 \mu \mathrm{M}$ BA for culture establishment. The $\mathrm{pH}$ of the medium was adjusted to 5.7 before autoclaving at $121^{\circ} \mathrm{C}, 125 \mathrm{kPa}$ for 20 min. Medium $(20 \mathrm{~mL})$ was dispensed into 25 $\times 140$-mm culture tubes capped with polypropylene closures (Bellco Kaputs, Vineland, N.J.). Cultures were grown at $18 \pm 2{ }^{\circ} \mathrm{C}$ under a 16-h photoperiod from cool-white fluorescent lamps $\left(\approx 50 \mu \mathrm{mol} \cdot \mathrm{m}^{-2} \cdot \mathrm{s}^{-1}\right)$.

Culture maintenance. The cultures were transferred every 4 weeks to $55 \times 70$-mm jars containing the establishment medium $(40 \mathrm{~mL})$ previously described and capped with polypropylene closures (Magenta B-caps; Magenta Corp., Chicago). Experiments began when sufficient shoot material was obtained. Initial explants were $1.5 \mathrm{~cm}$ long. For succeeding subcultures, shoot explants originating from the previous culture were $\approx 0.5 \mathrm{~cm}$ long.

Shoot proliferation-Expt. 1. Three cytokinins were evaluated for their effects on shoot development. Shoots $(0.5 \mathrm{~mm}$ long $)$ from cultures described above were transferred to a basal medium supplemented with kinetin (5.8, 11.6, 23.2, 46.0 $\mu \mathrm{M})$, TDZ ( 0.005, 0.05, 0.23, $0.45 \mu \mathrm{M})$, or BA $(5.5,11.1,22.2,44.0 \mu \mathrm{M})$, resulting in 12 treatments. Three shoots (subsamples) were placed in each jar with five jars (replications) per treatment.

Effect of culture age-Expt. 2. To test whether productivity declined with culture age. The 30-month-old cultures were placed on medium supplemented with $11.1 \mu \mathrm{M}$ BA and, subsequent to Expt. 1, transferred to medium supplemented with $5.5 \mu \mathrm{M}$ BA. Eightmonth-old cultures were multiplied and maintained on medium supplemented with $5.5 \mu \mathrm{M}$ BA. This concentration was the preferred treatment identified in Expt. 1. There were 15 jars (replications) for each treatment with three explants (subsamples) per jar.

Effect of treatment time period on shoot growth-Expt. 3. Shoots, $1.5 \mathrm{~cm}$ long, were harvested from 30-month-old stock cultures, previously described under "Culture maintenance," and moved simultaneously to basal medium supplemented with $5.5 \mu \mathrm{M}$ BA for the four treatment periods $(4,6,8$, and $4+4$ weeks). In the first three treatment periods, shoots were harvested and measured at 4,6 , and 8 weeks, respectively. In the last treatment, shoots were transferred to fresh medium without removal of axillary shoots after the first 4 weeks. Explants were harvested and measured after another 4 weeks ( 8 weeks total). Three shoots (subsamples) were placed in each jar with 15 jars (replications) per treatment. 
Rooting-Expt. 4. For the rooting experiments, shoots were harvested from 21-monthold cultures maintained on medium supplemented with $5.5 \mu \mathrm{M}$ BA. The harvested shoots were placed on a cytokinin-free medium for 30 days before transferring them to the experimental media containing either IBA or NAA. The nine rooting treatments were a control (no auxin); IBA at $0.5,4.9,12.3$, and $24.6 \mu \mathrm{M}$; or NAA at $0.5,5.4,13.4$, and $26.81 \mu \mathrm{M}$. Three shoots (subsamples) were placed in each jar $(55 \times 70 \mathrm{~mm})$ with five jars (replications) per treatment. Explants were cultured under the same conditions as previously described.

Acclimatization procedure. Rooted microcuttings were transferred to Magenta GA7 vessels (Magenta Corp.) containing RediEarth (W.R. Grace, Cambridge, Mass.). Plants were grown in the laboratory at $18 \pm 2{ }^{\circ} \mathrm{C}$ under 16 $\mathrm{h}$ photoperiods provided by Sylvania Grolux lamps (Sylvania, Westfield, Ind.; 70 $\left.\mu \mathrm{mol} \cdot \mathrm{m}^{-2} \cdot \mathrm{s}^{-1}\right)$. Plants were irrigated weekly using a liquid fertilizer solution. Plants were transferred to the greenhouse when roots were visible on the inner surface of the GA7 vessel ( $\approx 2$ to 4 weeks), repotted into a standard nursery container, and placed in a mist chamber for 1 week. Following acclimation in the mist chamber, plants were transferred to ambient greenhouse conditions, followed by transfer to an outdoor nursery, and planted in the field.

Data collection and statistical analysis. Data collected in Expt. 1 (shoot proliferation) were main shoot length, number of axillary shoots, and axillary shoot length. During rooting, data collected were main shoot length, primary root length, number of secondary roots, and secondary root length. Roots were measured by removing the explants from the media and destructively harvesting the shoots and roots. All experiments were set up in a completely randomized design and repeated. Explants within each jar were treated as subsamples. Data were tested using analysis of variance using the SAS program (SAS Inst., Cary, N.C.). Separation of means was performed by Tukey's highest significant difference (HSD) test.

\section{Results and Discussion}

Shoot proliferation-Expt. 1. There were no significant differences among treatments for main shoot length (ranging from 5.6 to 6.7 $\mathrm{mm}$ ) or axillary shoot length (ranging from 1.2 to $2.5 \mathrm{~mm}$ ). However, there were differences for the number of axillary shoots (Table 1). Overall, BA resulted in the maximum proliferation response, although it was not different from the lower concentrations of TDZ or the highest concentration of kinetin. At the concentrations tested for the growth regulators, kinetin was the least effective for shoot proliferation. Shoots produced on the TDZ treatments had a poor appearance, with some discoloration of the basal portion of the shoots and anthocyanins produced in the leaves. Evaluating the response of the shoots and quality of the shoots produced, $5.5 \mu \mathrm{M} \mathrm{BA}$ was chosen as the preferred treatment because it yielded the maximal number of shoots with the best quality and used the least amount of BA to produce the desired result.

Agarita micropropagation rates were higher than those reported for B. thunbergii DC. (Karhu and Hakala, 1991). Apical dominance was very strong in $B$. thunbergii DC. and decapitation of shoots was necessary to achieve shoot multiplication. The proliferation rate in agarita without decapitation is about double that of $B$. thunbergii DC. with decapitation. During more than 3 years of agarita subculture, shoot multiplication did not decline. This result is similar to those for Ulmus pumila $\mathrm{L}$. in which multiplication rates did not decline during 2 years of subculturing every 4 weeks (Corchete et al., 1993).

Effect of culture age-Expt. 2. Thirty- and 8-month-old cultures responded similarly for the three criteria measured (main shoot length, number of axillary shoots, and axillary shoot length) during 30 days in culture (data not shown).

Effect of treatment period on shoot growth-Expt. 3. Axillary shoot length was not affected by the duration of the subculture. There was little difference among the treatments for main shoot length or the number of axillary shoots. Main shoot length ranged from $6.5 \mathrm{~mm}$ at 8 weeks to $7.3 \mathrm{~mm}$ at 6 weeks and did not increase with longer subculture periods. The number of axillary shoots did not differ among the 4-, 6-, and 8-week subculture periods. The $4+4$-week treatment resulted in 5.2 axillary shoots. This was a significant increase over the 8-week subculture period (3.6 shoots), but was not different from the 4or 6-week periods (4.3 shoots). Accordingly, the 4-week subculture period was selected because it would result in the most shoots over a given period.

Rooting-Expt.4. Preliminary experiments with $1.0 \mu \mathrm{M}$ NAA resulted in nearly $100 \%$ rooting of shoots from cultures $<6$ months old (data not shown). However, rooting experiments with shoots from 21-month-old cultures suggest a decline in rooting ability as cultures aged. Only a few shoots rooted $(2.2 \%)$ in initial experiments with these cultures. Root initials appeared after 3 weeks in culture from those treatments that produced roots (data not shown). The poor rooting in shoots harvested from the older cultures could be the result of residual accumulation of BA in the explants. Rooting was successful in experiments in which a cytokinin-free subculture period preceded transfer of the microcuttings to medium containing auxin. Those microcuttings maintained on media containing $4.9 \mu \mathrm{M}$ IBA, $12.3 \mu \mathrm{M}$ IBA, or $5.4 \mu \mathrm{M}$ NAA had rooting percentages of $79 \%, 67 \%$, and $68 \%$, respectively (Table 2 ). Microcuttings from the control, IBA $(0.5 \mu \mathrm{M})$, and NAA $(26.8 \mu \mathrm{M})$ treatments did not produce any roots and were dropped from the analysis. Shoots that rooted formed a single primary root, ranging from 1.2 to $18 \mathrm{~mm}$ long, that would often branch and form secondary roots. Although there was no difference among treatments for primary root length or the number of secondary roots formed, 5.4 $\mu \mathrm{M}$ NAA was selected as the best treatment after considering the combination of rooting percentage
Table 1. The effect of kinetin, thidiazuron (TDZ), and benzyladenine (BA) on axillary shoot count.

\begin{tabular}{lc}
\hline $\begin{array}{l}\text { Cytokinin } \\
(\mu \mathrm{M})\end{array}$ & $\begin{array}{c}\text { Axillary } \\
\text { shoot count }\end{array}$ \\
\hline Kinetin & \\
5.8 & $1.3 \mathrm{cb}^{\mathrm{z}}$ \\
11.6 & $1.1 \mathrm{cb}$ \\
23.2 & $1.4 \mathrm{cb}$ \\
46.0 & $1.8 \mathrm{a}-\mathrm{c}$ \\
TDZ & \\
0.005 & $2.6 \mathrm{a}-\mathrm{c}$ \\
0.050 & $2.1 \mathrm{a}-\mathrm{c}$ \\
0.230 & $0.6 \mathrm{c}$ \\
0.450 & $0.7 \mathrm{c}$ \\
BA & \\
5.5 & $3.8 \mathrm{a}$ \\
11.1 & $3.0 \mathrm{ab}$ \\
22.2 & $3.0 \mathrm{ab}$ \\
44.0 & $2.2 \mathrm{a}-\mathrm{c}$ \\
\hline
\end{tabular}

${ }^{2}$ Mean separation by Tukey's HSD test at $P<0.05$. The mean values are from 10 replications (jars) with three subsamples (explants) per jar.

Table 2. The effect of naphthaleneacetic acid (NAA) and indolebutyric acid (IBA) on rooting of agarita microcuttings.

\begin{tabular}{ccc}
\hline \hline $\begin{array}{l}\text { Auxin } \\
(\mu \mathrm{M})\end{array}$ & $\begin{array}{c}\text { Rooting } \\
(\%)\end{array}$ & $\begin{array}{c}\text { Secondary root } \\
\text { length }(\mathrm{mm})\end{array}$ \\
\hline IBA & & \\
4.9 & 79 & $1.9 \mathrm{ab}^{\mathrm{z}}$ \\
12.3 & 67 & $3.1 \mathrm{ab}$ \\
24.6 & 40 & $5.9 \mathrm{a}$ \\
NAA & & \\
0.5 & 17 & $0.7 \mathrm{ab}$ \\
5.4 & 68 & $4.0 \mathrm{ab}$ \\
13.4 & 20 & $0.1 \mathrm{~b}$ \\
\hline
\end{tabular}

${ }^{\mathrm{z}}$ Mean separation by Tukey's HSD test at $P<0.05$ The mean values are from 10 replications (jars) with three subsamples (explants) per jar. Microcuttings from the control, IBA $(0.5 \mu \mathrm{M})$, and NAA $(26.8 \mu \mathrm{M})$ treatments did not produce any roots and were dropped from the analysis.

$(68 \%)$ and primary $(18 \mathrm{~mm})$ and secondary $(4.0 \mathrm{~mm})$ root lengths. Using this treatment, agarita microcuttings were rooted, acclimatized as previously outlined, and transferred to field plots, with $>95 \%$ of the plants surviving in the field.

Unlike B. thunbergii DC., where rooting was initiated in darkness, agarita rooted in light. The decline in agarita microcutting rooting ability differs from many other woody plants. For example, peach (Prunus persica L. Batsch.) microcutting rooting percentages sharply increased with length of time in vitro (Hammerschlag et al., 1987). Another notable difference in the rooting pattern of agarita from other plants is the formation of a single root in vitro, with secondary roots, rather than the formation of multiple roots from the base of the microcutting.

\section{Conclusions}

The most efficient micropropagation protocol for agarita tested was WPM basal medium supplemented with $5.5 \mu \mathrm{M}$ BA and a subculture period of four consecutive weeks with three shoots per jar. Several factors suggest that initiating new cultures each year 
would be the best method of micropropagation. Among these are 1) rooting percentages are higher using lower concentrations of auxins with microcuttings from new cultures than with microcuttings from older cultures; 2) a subculture on hormone-free medium is necessary for rooting microcuttings from older cultures and; and 3) new cultures are easy to establish each year.

\section{Literature Cited}

Corchete, M.P., J.J. Diez, and T. Valle. 1993. Micropropagation of Ulmus pumila L. from mature trees. Plant Cell Rpt. 12:534-536.

Hammerschlag, F.A., G.R. Bauchan, and R. Scorza. 1987. Factors influencing in vitro multiplication and rooting of peach cultivars. Plant Cell Tissue Organ Cult. 8:235-242.

Karhu, S.T. and K.H. Hakala. 1991. Micropropagation of Berberis thunbergii. Acta Hort. 289:119-120.

Lloyd, G.B. and B.H. McCown. 1980. Commercially-feasible micropropagation of mountain laurel, Kalmia latifolia, by use of shoot-tip culture. Proc. Intl. Plant Prop. Soc. 30:421-427.

Murashige, T. and F. Skoog. 1962. A revised medium for rapid growth and bioassays with tobacco cultures. Physiol. Plant. 15:473-497.

Nokes, J. 1986. How to grow native plants of Texas and the Southwest. Texas Monthly Press, Austin. 